\title{
Colonized Severing the Cords of the Colonizer: A Research of Various Aspects of Colonization in the Hadassah: One Night with the King
}

\author{
Crispine Shiny, D. David Wilson, R. Corneli Agnes Rosabella
}

\begin{abstract}
Colonization can be traced clearly in the novel Hadassah: One Night with the King. Esther is the slave girl of the Persian Empire under the reign of King Xerxes, a resident at the citadel of Susa. Having control over 127 provinces from Ethiopia to India, King Xerxes had also made Israel his colony. The Jews in captivity have been assigned menial jobs from standing at the entrance of the court and saluting the visitors to scribe writing. Both men and women have been taken as slaves to work in the royal chambers. Besides this, another group of people called Agagites suppress them. The Jews face double colonization.

This paper focuses on how a 'voice of deliverance' emerges from the voiceless, oppressed nation. Queen Esther, a colonized woman, rises to the rank of a Queen and saves her people from getting wiped out entirely. The Jews continuously were colonized by super powers. Finally, they broke the bondages of the lurking dangers by being led by Queen Esther.
\end{abstract} Jews.

Keywords: Colonization, Post- Colonial, Slave, Esther, Persia,

\section{INTRODUCTION}

The novel Hadassah one night with the King is written by Tommy Tenney a renowned author of many books. He is a living author who hails from America. He is well-Known for his God Chaser's series. Among many novels Hadassah: one night with the king is a famous one. The novel reached the heights of film making and has been captured in the form of a full-fledged movie. The main idea of the novel has been borrowed from The Bible, the book called Esther of the Old Testament. This novel is a retold version of Esther in an elaborate way with 52 chapters. Though, in the Bible the book of Esther ends with 12 chapters and without referencing the word 'God'.

The commencement of the twentieth century marked the liberation of colonized countries. The writers of the free nations wanted to express their feelings and emotions through their works. This marked the beginning of a new theory in literature. This theory is termed as postcolonialism. The emergence of post-colonialism has indeed given a new theory in literature. "Post Colonialism, like other post-isms, does not mark an end of that which it contains (that is, colonialism), but rather a beginning of a

\footnotetext{
Revised Manuscript Received on 14 August, 2019.

Crispine Shiny, Ph.D Scholar, Karunya Institute of Technology and Sciences, Coimbatore, Tamil Nadu, India. (Email: crispineshiny.7@gmail.com)

Dr. D. David Wilson, Associate Professor, Karunya Institute of Technology and Sciences, Coimbatore,Tamil Nadu, India. (Email: davidwilson@karunya.edu)

Dr. R. Corneli Agnes Rosabella, Assistant Professor, Karunya Institute of Technology and Sciences, Coimbatore, Tamil Nadu, India. (Email:
} rosabella@karunya.edu). field of investigation and understanding following a period of relative closure" (Chandra; 358).

The main idea of post colonialism is that it rejects the concept of universalism. Peter Barry in his Beginning Theory says, "This universalism is rejected by post- colonial criticism whenever a universal signification is claimed for a work, then, white, Eurocentric norms and practices are being promoted by a sleight of hand to this elevate status, and all others correspondingly relegated to subsidiary marginalized roles" (Barry; 192)

\section{THE KEY PRINCIPLES OF POSTCOLONIAL LITERARY THEORY}

Postcolonial Literary Criticism attempts to decentralize the concept of colonization. The postcolonial approach can be divided into three main parts. According to the book Classical Contemporary Literary Theory by Joseph Chandra it brings out some important points of Post-colonialism are;

1. National/regional models emphasize on the distinctive features of national or regional history and culture.

2. Racial/Ethnic models the idea of race has been a major feature of Euro American economic, Political and cultural practice.

3. Colonizer/colonized models concentrate on the imperial-colonial dialectic. Fanon is the founding father of postcolonial theory. He states that whether the native intellectual could escape the hegemony of colonizing culture.

History records that Cyrus ascended the throne of Persia in 559 B.C; he became the founder of the Achaemenid dynasty. In a string of military victories, Cyrus proceeded to conquer the largest territory in history, stretching from the Indus River to central Anatolia. The first major victories allowed Cyrus to successfully unite the Persian tribes and the Medes into a mighty kingdom. After defeating the Median Empire and its last king, Astyages, in 550 B.C., Cyrus declared himself the successor to the Median Kings. Just 3 years later, in 547 B.C., a victory over Lydia and king, Croesus, expanded Cyrus's empire toward Greece (Nelson 903).

Cyrus died in 530 B.C; and his son Cambyses succeeded the throne. There are some indications that Cambyses was mentally unstable and perhaps epileptic, but he evidently inherited some of his father's ability as a general. Later Cambyses committed suicide. One of his officers, named 


\section{COLONIZED SEVERING THE CORDS OF THE COLONIZER: A RESEARCH OF VARIOUS ASPECTS OF COLONIZATION IN THE HADASSAH: ONE NIGHT WITH THE KING}

Darius, took his place. Darius put down the rebellion and several others in the next few years, and in the end it was Darius who reigned as the next Persian emperor. Under the rule of Darius, the extensive organization of the Persian Empire took place. The resulting system of regional governors, satraps, and official inspectors was bulky and effective. During Darius reign, a new player appeared in the political life of the ancient Near East: Greece. Darius expanded the Persian Empire throughout the region of Asia Minor and sought to go to the next step, into the Greek peninsula. The Greek alliance turned Darius's armies back at the battle of Marathon in 490 B.C. Darius's son Xerxes invaded the Greece again in 480 B.C (Nelson; 903).

From the time of Babylonian invasion up to the reign of Persian Kings, Jewish people were colonized and treated with cruelty. The Jewish were suppressed by the Persian rule, they were deprived the freedom of expression, they were enforced to pay tax and show allegiance to Persian rulers. King Xerxes ruled 127 provinces from India to Ethiopia (Spoelstra). Under his control, many colonies survived. Among the many colonizers was a tribe called Amalekite, had an iron hand over them. Haman the descendant of Amalekite also known as Agagite is considered to be the seed of destruction for the Jews. When King Saul invaded Amalekite and Agag, its King, he failed to destroy the things belonging to the Amalekite. Because of his folly, the Queen of Amalekite escaped with the seed of vengeance. In the later days that seed of vengeance appeared in the form of Haman. His only purpose of life was to extinguish the tribe of Jews. He used his upper hand of power and authority to make his ancestor's dream come true. These are the words of revenge from the mother of Agagite:

Kill anyone you find, even if it costs you, your life. Their death is your blood, your reason for living. Someday one of your offspring will find a way to kill them all. $[\ldots]$ Five centuries later, the right descendant was born not far from where his ancestral mother had given birth to Agag's son. His generation would be the one to stage the ultimate revenge. That man was named Haman (Hadassah: One Night with the King 44).

\section{NATIONALLY COLONIZED}

'Nationally colonized' means the citizens of the particular nation are colonized under a particular rule like that of dictatorship. The citizens of that community are ill treated and they are considered as mere slaves for them. They cannot enjoy their own right to freedom of speech, right to seek or redressed. They have limitation in all aspects and cannot enjoy their life. These people are treated like animals in the hands of their master. By using these people they build giant structures for e.g. the Egyptian constructed pyramid by using their slaves and making them to work in mines etc. Exploitation of the slaves is a common feature. They suck their blood to produce a master piece of work for exhibition (Nadar).

In the novel, Hadassah: one night with the king the Jews were colonized by Persians. They have to do all kinds of labour for a paltry sum of pay. The people were treated harshly and controlled by the authorities. When Hadassah and her parents lived in Babylon under the rule of King
Darius, he conquered Egypt. The Egyptians were not cooperating well with the Persian soldiers. Once When Satrap Xeril Artemis met Haman on the way, he became very happy to get the friendship of Satrap. During their conversation Satrap asked Haman's help to plunder and ruin the Egyptian city.

Attack Egypt? Well, maybe not attack the entire nation. Our armies will do plenty of that in time. But harass, maybe. Pester their nethermost outposts.

Weaken their defenses. Distract their scouts. If you can burn a city or two, all the better (HNK 2004).

Through the above quote it is very much clear that the Satrap Xeril wants to show his authority over Egyptian and to prove his strength over them. Haman a wicked person wants to destroy the lives of any tribe in order to win the favor of his higher officers.

Haman revealed his heart's desire when Satrap Xeril told him to treat the Egyptian cruelly. "Can I kill any Jews I find" (HNK 55). To Haman's question Satrap replied that he was not against his wish but they should be treated like any other local civilians. For this reply he became very happy and his physical appearance changed. "Haman rubbed his hands together, his eyes gleaming. Sir, consider me the newest and most willing raider in your Persian army. Call me your advance force, if you will" (HNK 55). These words stood as an approval for his act and he was not bothered to kill anyone until he attains his goal of vanishing Jews from his eyesight. Thereafter he carried out his mission of raid successfully and killed many Egyptian, Babylonian and Jews (Gertoux), (Green).

During that time Hadassah was a small girl and her parents stayed in Jewish colony in Babylon. It was Hadassah's birthday and she received a precious gift from her mother. Her great grandparents brought a chain with star pendant from the promise land. The significance of this pendant is when the pendant is shown in light it reflects the Star of David, the symbol of King David in the room. This reflection catches the attention of baby Hadassah and she was very thrilled to wear it on her birthday. After wearing the star pendant chain, she requested her mom to allow her to wear for one more night. But her joy couldn't last long. That night raided their home. When she heard a disturbing sound in her sleep she hid herself under the blanket. Her parents were killed by Haman and his troops but she had a lucky escape from the hands of Haman. To quote:

My young friend is how a band of Hebrew - hating Amalekites came to be in Babylon, far from their native territory, massacring not only my father Abihail's family but many Jewish homes in the city and some of Babylon's leading citizens. The blood of my family won Haman great favor within the Empire (HNK 56).

Hiding one's identity was very much common among the Jews due to the fear of losing their lives. Hadassah was strictly warned by Mordecai of her identity. It is often found in Jews history that when a person is taken as a slave from another country they are not supposed to say their original name (Alfaro). In the case of Hadassah and Jesse when they

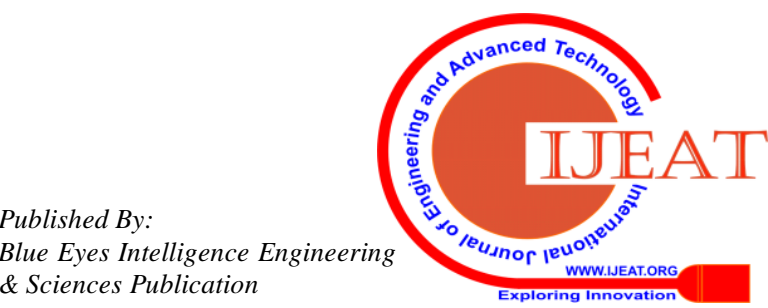


were taken into the palace, the same rule was followed. According to Joshua Alfaro Esther's name simultaneously suggests the verb star, she will hide herself. Precisely by taking on another name, Esther is able to facilitate hiding her true identity (Alfaro).

Mordecai warns Hadassah that not to tell anyone about her Jewish identity. "Tell no one of your Jewishness, he muttered over and over again. It will become an issue. It could actually mean your life" (HNK 136). When Mordecai is notified about new order of finding a new Queen, he was very afraid about Hadassah and her life so he insisted that how dangerous for Jews to reveal their nationality and origin. In order to hide the nationality Mordecai dressed up like a Persian with long beard and chain around his neck (Paton), (Pealman).

When Hadassah was taken as a Queen candidate for the Persian Queen Contest, she was asked about her name and she said Star of Susa because she knew the alarming sound of Mordecai ringing in her heart that not to reveal her identity. The other reason was that there were many enemies around her with waves of vengeance (Lyles), (Schuster). Thus, they were colonized within their nation even to the extent of hiding the original names. When Hegai asked Hadassah her name for the first time, she replied in these words;

What is your name, my dear? "Ha- I started, intending to give my full name, but I then realized that its Jewishness might give me away. "Star, I said weakly, recalling the beloved necklace given to me as a child "My name is Star" (HNK 141).

Therefore it is clear that the colonized were unable to reveal their true identity. The same rule was applicable to Jesse, the grandson of Rachel, a Jewish maid who worked in Mordecai's house and took care of Hadassah. When the Kings Court looked for a candidate to be the new queen of Persia, Jesse was taken forcefully from the street of Susa to work as a eunuch in Kings Court. There was a need for fifty men in the king's court in order to assist the new queen candidate. Jesse's name too got changed once he entered the Court as Hathach.

I am now Hathach. I hate it. My real name came from the line of David. I don't even know where Hathach came from. For all I know, it is some pagan god. Remember our Jewish brothers Daniel, Hananiah, Mishael and Azariah? They were all given pagan names when they entered royal service. And look how G-d remained with them and used them to accomplish His purposes. Besides you will always be Jesse to me (HNK 172).

Hadassah met Jesse in the king's palace. She came to know about Jesse and his name conversion. She felt sorry for it and referred to the young Jewish men taken as slave in Babylonia. Even their names were changed to pagans as Shadrach Meshach and Abednego. But they were the most wise and skillful men in the whole kingdom. In the same manner, Jesse would also be a person of impact in later. With these words of hope Hadassah consoled Jesse during their secret meeting in the Court (Alfaro).

\section{DOUBLE COLONIZATION OF WOMEN}

Hadassah was brought up with much care and concern. She was a pampered girl by her poppa. She had been in the
Jewish colony of Susa. She was not permitted to go out of her house at any cost. The outside Persian lifestyle was totally hidden to her due to the risk of her life and virginity. Therefore she had to spend her time with Rachel, Jesse and Mordecai inside the house. She didn't even learn the Persian language. Since Mordecai was a scribe in the King's Court he was well versed in Persian and Jewish languages. In the evening time, Mordecai taught Hadassah to read Persian script. Thus, Hadassah and other women were colonized doubly as Jews as well as a woman. Just as the colonial suffering of black women in the name of race and Indian women in the name of caste (Dominic). Beyond all the rules and restrictions of the society Hadassah wanted to explore the outside world. So, she disguises herself as a boy.

Rachel you know how badly I wish to see the city. Would you dress me up to look like a boy? Maybe even a nonJewishone, why not Jewish and so I walked out of Mordecai's door for the first time in years. Alone (HNK 92, 93, 94).

It's a clear evidence of how women were suppressed in the Persian reign. They were under the dominance of male power. Women were controlled even to the extent of keeping away from the market place. They depended on males even to buy any things for their livelihood (Auguste).

\section{POLITICALLY DUAL COLONIZATION\& RESULTS}

The people were doubly colonized by Persian and Agagites. They were treated as slaves. Haman, an AntiSemite was exalted to the position of master of Audience. King Xerxes advanced him and established his authority over all the princes who were with him. Everyone in the King's gate bowed down and paid homage to Haman. The servants who were at the king's gate said to Mordecai, "Why are you transgressing the King's command?" (Swindoll 32). It was told to him every day and he would not mind them. They informed Haman of Mordecai's behavior and disclosed that he was a Jew.When Haman saw that Mordecai neither bowed down nor paid reverence to him, He was loaded up with fury. He hated to lay hands on Mordecai, for they had revealed to him who the general population of Mordecai were (Swindoll 32).

The roots of Haman's bitterness toward the Jews could be traced back from his family tree. He was a descendant of Agag, the Amalekite king. The Amalekites had remained bitter enemies of Jews, and the feud was taken up by Haman. Prejudice is a vicious evil. And it's hereditary, passed down from generation to generation. When Mordecai refused to bow down, the Anti- Semitic hair on the back of Haman's neck stood on.

Mordecai refused to bow down for two reasons first the act would be considered idolatry by a Jew. Second, Mordecai didn't want to show respect to an Amalekite, an avowed enemy of his people. Haman's hatred seethed in a caldron that spilled over not only on Mordecai but on all of Mordecai's people. Not only Haman wanted to kill Mordecai but his plan was to kill the entire race of Jews (Swindoll 33), (Simon). 


\section{COLONIZED SEVERING THE CORDS OF THE COLONIZER: A RESEARCH OF VARIOUS ASPECTS OF COLONIZATION IN THE HADASSAH: ONE NIGHT WITH THE KING}

Haman is a prime example of just how deceitful and desperately wicked the human heart can be. It was from the murky depths of hearts like Haman's that the Holocaust dredged up. Haman had plenty of time to execute the fate of the Jews as he waited for his number to come up to be brought before the king. In the month of Adar, he thought of establishing his plan. He presented his scheme before the King stating that there were a certain people scattered and dispersed among the peoples in all provinces of Persia; their laws were different from those of all other people, and they did not observe the King's law, so it was not in the King's interest to let them remain (Guinness).

Eradicate them? They are not numerous in Susa but all across the Empire. They are so relentless, so unceasing in their vile efforts, that the only way to save your kingdom is to make an example of them. Kill them all. I will pay into the treasury ten thousand talents of silver upon the issuance of a royal edict authorizing their (HNK 290).

The above quote clearly depicts the magnitude of double oppression suffered by the Jews. They were already under the control of Xerxes and again they are suppressed by the Amalekite. When Amalekites went for a raid in Jews quarters to plunder, kill and destroy Jews property and people. Jews and Amalekites were also under the same rule of Persian King who ruled 127 provinces. Still, this Amalekites had an upper hand on Jewish especially; Haman misused his power in order to quench his revenge on Jews. The Jews were the victims of torture and physical abuse.

When Haman is charged all lie against the Jews, the King gets trapped by his smooth talk and slowly changed his view on these people. Haman even told the lie that previous master of Audience Memcuan was murdered by the Jews. As a slow poison, Haman worked in the mind of King and made his plans being executed. To precede one step ahead, he corrupted the Kings thought by adding ten thousand silver talents in the royal treasure. Haman assured the King that he would support the royal fund if his wish of killing all the Jews in 127 provinces was accepted.

King had a blind faith on Haman without rechecking his statement or verifying the accusation on the Jews. Ultimately, the Jewish community had to suffer. The whole community was under risk of life. Queen Esther being a Jew never revealed her identity to her husband King Xerxes because of the dire consequences. When she heard about this turmoil, she couldn't bear the pain of losing all her race in one strike. She declared a three day fast where the whole Jewish community had to humble themselves and cry for God's favor and mercy to escape this massacre. Finally, she went to the court of Xerxes pleading for his mercy. She won the favor of the King and stopped the great danger for the whole tribe of Jew (Merrill).

\section{CONCLUSION}

Jewish people were ill treated doubly both by the higher authority and the subordinate authorities of the country. From the above lines it is clear that the people faced affliction and suffering in the form of colonization the Jewish were suppressed nationally because of the hatred of Haman. A Jewish woman has to undergo many struggles because they are Jews and secondly they are born as woman. Double colonization was very much seen the case of Jewish people first they are colonized by Persian second they are treated cruelly by the Amalekite. Colonization bent the people and added many yoke on them. Especially, In the case of Jews they had to face life or death challenge. Colonization has ruined their lives and property and they had to face the hardships in life by moving along with the slaughter. During Esther's time things take a dramatic change when the Jewish community is saved by Divine Providence, Esther's prayer and Mordecai's prudence. The colonized people server the cords of the colonizer.

\section{REFERENCES}

1. Tenny, Tommy and Olsen Andrew Mark. Hadassah: One Night with the King. USA: Bethany house, 2004. Print.

2. ---, Hadassah: The girl who became Queen Esther. USA: Bethany house, 2005. Print.

3. ---, The Hadassah Covenant. USA: Bethany house, 2005. Print.

4. ---, Finding favor with the King. USA: Bethany house, 2003. Print

5. Ashcroft, Bill Gareth Griffiths and Helen Tiffin. The Empire Writes Back. New York: Routledge, 1989. Print.

6. Barry, Peter. Beginning Theory: An Introduction to Literary and Cultural Theory. United Kingdom: Manchester, 1995. Print.

7. Chandra, N. D. R. Contemporary Literary Criticism: Theory and Practice. Vol I. New Delhi: Authors press, 2005. Print.

8. Chandra, Joseph and K.S. Antony Samy. Classical to Contemporary Literary Theory. India: Chennai, 2010. Print.

9. Kaushik, Abha Shukla. Post modern Indian English Fiction. Delhi: Aadi Publication, 2012. Print.

10. Dominic, K.V. Critical studies on Contemporary Indian English Women Writers. New Delhi: Sarup Book Publishers, 2010. Print.

11. Pealman, Myer. Through the Bible book by book Genesis to Esther.USA: Gospel Publishing House, 2012. Print.

12. Nadar, Sarojini. "Gender, Power, Sexuality and Suffering Bodies in the Book of Esther: Reading the Characters of Esther and Vashti for the Purpose of Social Transformation." Old Testament Essays 15/1 (2002): 113-130.

13. Paton, Lewis B. A Critical and Exegetical Commentary on The Book of Esther. International Critical Commentary. Edinburgh: T \& T Clark, 1976.

14. Gertoux, Gerard. "Queen Esther wife of Xerxes Chronological, Historical and Archaeological Evidence" University Press of America: 2002.

15. Green, Alexander. "Power, Deception, and comedy: The Politics of Exile in the Book of Esther" Jewish political studies Review; Spring 2011; 23, 1/2.

16. Spoelstra, Joshua Joel. "Surving the Agagites: A Postcolonial Reading of Esther 8-9" OTE 28/1 2015: 168-181.

17. Alfaro, Joshua. "Hiding Hadassah: The Meaning and Function of the Name Esther and Mordecai in MT Esther" pg 1-16.

18. Simon, Moshe David. "Many Thoughts in the Heart of Man: Irony and Theology in the Book of Esther" 1997 Rabbinical council of America, Tradition 31: 4.

19. Swindoll, Charles R. Esther a woman for such a time as 
this. California: Insight for living, 1990. Print.

20. Guinness, Alma E. Mysteries of the Bible the enduring Questions of the Scriptures. New York: Reader's Digest, 1988. Print.

21. Merrill, Eugene. An historical survey of the old testament. New Jersey: The craig press, 1966. Print.

22. Schuster, Ignatius. Illustrated Bible History. India: St. Paul Publications, 1963. Print.

23. Lyles, Ron. Bible Book Study Commentary, Ezra Nehemiah, Esther. Tennessee: Sunday school board, 1995. Print.

24. Nelson, Thomas. Chronological Study Bible explore God's word in Historical order. Harper Collins Christian Publishing, 2014. Print.

25. Auguste, Princess O Nika. "Was Esther a Post-Colonial Feminist?" Christian Feminism Today, Web. 31 May. 2019. 